\section{The examination of the} secondary school student's attitudes toward physical education lesson and their academic motivation according to some variables (Burdur province sample) $^{1}$

\section{Ortaöğretim öğrencilerinin beden eğitimi dersine ilişkin tutumlar1 ve akademik güdülenme düzeylerinin bazı değişkenlere göre incelenmesi (Burdur il merkezi örneği)}

\author{
Vedat Uluış1k ${ }^{2}$ \\ Malik Beyleroğlu ${ }^{3}$ \\ Gürhan Suna ${ }^{4}$ \\ Seda Yalçın ${ }^{5}$
}

\begin{abstract}
In this study, it was aimed to examine the examination of the secondary schoolstudent's attitudes toward physical education lesson and their academic motivation according to some variables. 191 femaleand 194 male, totally 385 secondary school students from Uso Anatolian High School, Mehmet Uzal Sosyal Sciences High School, Emekevler Vocationaland Technical Anatolian High School, and Burdur Vocationaland Technical Anatolian High School in Burdur Province were involved during 20152016 academic year in this research. In this study, 'Attitude Scale For Secondary School Student's' developed by Güllü and Güçlü (2009) and 'Academic Motvation Scale' developed by Bozanoğlu (2004) were used as data collection tools.
\end{abstract}

Statistical analysis of the data obtained from the research was made by using SPSS 22.0 Spearman Correlation Analysis was applied to examine the relationship between the Attitude Scale Toward Physical Education Lesson and
Özet

Yapılan bu araştırmada, ortaöğretim öğrencilerinin beden eğitimi dersine yönelik tutumları ve akademik güdülenme düzeylerinin bazı değişkenlere göre incelenmesi amaçlanmıştır. Araştırmaya 2015-2016 eğitimöğretim yllinda Burdur il merkezinde bulunan Uso Anadolu Lisesi, Mehmet Uzal Sosyal Bilimler Lisesi Emekevler Mesleki ve Teknik Anadolu (Kuz Meslek) Lisesi ve Burdur Mesleki ve Teknik Anadolu (Endüstri Meslek) Lisesi'nde öğrenim gören 191 kadın ve 194 erkek olmak üzere toplam 385 ortaöğretim öğrencisi katılmıştır. Araştırmada veri toplama aracı olarak Güllü ve Güçlü (2009) tarafindan geliştirilen "Ortaöğretim Öğrencileri İçin Beden Eğitimi Dersi Tutum Ölçeği" ve Bozanoğlu (2004) tarafindan geliştirilen "Akademik Güdülenme Ölçeği” kullanılmıştır.

Araştırmada elde edilen verilerin istatistiksel analizi SPSS 22.0paket programı kullanılarak yapılmıştır. Beden Eğitimi Dersine İlişkin'Tutum Ölçeği ve Akademik Güdüleme Ölçeği’nin

\footnotetext{
1 This paper is presented at ERPA International Congresses on Education 2016, June 2-4, 2016, Sarajevo.

2 Ph.D. Student, , Institute of Educational Sciences, Sakarya University, Department of Physical Education and Sports Education, vedat151515@gmail.com

3 Associate Prof., Sakarya University, School of Physical Education and Sports, mbeyler@sakarya.edu.tr

${ }^{4}$ Ph.D. Student, Sakarya University, Institute of Educational Sciences, Department of Physical Education and Sports Education,gürhan suna@windowslive.com

${ }^{5}$ Post Graduate, Sakarya University, Physical Education and Sports Teaching, y.seda@hotmail.com
} 
Ulusşık, V., Beyleroğlu, M., Suna, N., \& Yalçın, S. (2016). Ortaöğretim öğrencilerinin beden eğitimi dersine ilişkin tutumları ve akademik güdülenme düzeylerinin bazı değişkenlere göre incelenmesi (Burdur il merkezi örneği). Journal of Human Sciences, 13(3), 5092-5106. doi:10.14687/jhs.v13i3.4026

Academic Motivation Scale. Mann Whitney U, Kruskal Wallis $\mathrm{H}$ test were applied for the other analysis and significance level was identified as ' $\mathrm{p}<0,05$ ' in all the analysis. As a result of the study, it was determined that there was a linear (low) and significant relationship between the attitude level of participants toward physical education lesson and their academic motivation level. $(\mathrm{p}<0,05)$

Keywords: Physical Education; Sports; Attitude; Academic Motivation.

(Extended English abstract is at the end of this document) birbirleriyle arasında ilișkinin incelenmesinde Spearman Korelasyon analizi uygulanmıştur. Diğer analizler için Mann Whitney U, Kruskal Wallis $\mathrm{H}$ testleri uygulanmış ve bütün analizlerde anlamll1k düzeyi " $\mathrm{p}<0,05$ ” olarak belirlenmiştir. Araştırma sonucunda katıllımciların beden eğitimi dersine ilişkin tutum düzeyleri ile akademik güdüleme düzeyleri arasındal doğrusal (zayıf) ve anlamlı bir ilişki varlığı tespit edilmiştir $(p<0,05)$.

Anahtar Kelimeler: Beden Eğitimi; Spor; Tutum; Akademik Güdülenme.

\section{Giriş}

Beden eğitimi; insanları bedensel, ruhsal ve fikren geliştiren, olgunlaştıran, en az yorgunluk ile en fazla verim elde edilmesini sağlayan oyun, jimnastik ve spor etkinliklerinden oluşan bilim dalı olarak tanımlanmaktadır (Açak, 2006). Diğer bir tanıma göre beden eğitimi "bireysel ya da takım eşliğinde gerçekleştirilen, belirli plan ve programa bağlı olan, fiziksel ve zihinsel bir ön hazırlık gerektiren, belirli bir amaca yönelik olan hareketler bütünü” şeklinde tanımlanmıştır (Çoban ve Ünveren, 2007). Daha geniş kapsamlı ele alındığı zaman beden eğitimi; Bireyin bedensel, sosyal, zihinsel ve motorsal yönden gelişmesini amaçlayan, belirli kurallar çerçevesinde gerçekleştirilen, genel olarak bedensel etkinliklerden meydana gelen sistemli bir eğitim faaliyetidir. Eğitim sistemi içerisinde beden eğitimi ve spor dersleri öğrencilerin fizşksel etkinlikler yoluyla öğrenmelerine katkı sağlayan bir derstir. Beden eğitimi ve spor dersleri öğrencilerin gelişimlerini birçok açıdan desteklediği için ülkelerin eğitim sistemleri içerisinde en fazla önem verilen derslerin başında beden eğitimi ve spor dersleri gelmektedir (Hekim, 2015). Yapılan tanımlar değeerlendirildiği zaman, beden eğitimi ve spor dersinin sadece bedensel açıdan değil (Hekim, 2016), psiko-sosyal ve toplumsal gelişim açısından da önemli bir eğitim faaliyeti olduğu görülmektedir (Uluışı, 2015). Nitekim literatürde yer alan araştırma bulguları da beden eğitimi ve sporun bedensel gelişimin yanında psiko-sosyal ve toplumsal açıdan gelişimi desteklediği görüşünü desteklemektedir (Salar vd., 2012; Hekim vd., 2012; Keskin vd., 2014; Şahin ve Işıtan, 2010). Kangalgil ve diğerleri'ne (2006) göre, modern anlayışa uygun olarak eğitim amaçlarının gerçekleştirilmesi bireyin, zihinsel eğitiminin yanında fiziksel açıdan da eğitilmesi ile mümkündür. Bu noktada hareketler yoluyla öğrenmeyi amaçlayan beden eğitimi ve spor dersi genel eğitimin vazgeçilemez bir parçası olarak değerlendirilmektedir.

Insanların içinde bulundukları çevrede karşılaştıkları olgu ya da nesnelere yönelik tepki eğilimleri "tutum" olarak tanımlanmaktadır. Diğer bir ifade ile tutum, insanların karşılaşmış oldukları durum ya da olaylar karşısında ortaya koymaları beklenen davranış biçimi olarak ifade edilmektedir. İnsanların sahip oldukları tutumlar sadece karşılaştıkları olay ya da durumlara yönelik olmayıp, insanların diğer insanlara, bir eşyaya veya soyut bir duruma (yüce, iyi, kötü, mutluluk, mutsuzluk vb.) karşı da tutum geliştirmeleri mümkündür (İnceoğlu, 2010). İnsanların sahip oldukları tutumlar seergilenecek olan davranışlanı doğrudan ya da dolaylı olarak etkilemektedir. Bu nedenle literatürde tutum üzerine yapılan araştırmaların hala güncelliğini koruduğu görülmektedir (Güllü ve Güçlü, 2009). 
Uluıșık, V., Beyleroğlu, M., Suna, N., \& Yalçın, S. (2016). Ortaöğretim öğrencilerinin beden eğitimi dersine ilișkin tutumları ve akademik güdülenme düzeylerinin bazı değişkenlere göre incelenmesi (Burdur il merkezi örneği). Journal of Human Sciences, 13(3), 5092-5106. doi:10.14687/ihs.v13i3.4026

Tutumu olușturan üç öğe bulunmaktadır. Söz konusu öğeler zihinsel öğe, duygusal öğe ve davranışsal öğedir. Tutumu oluşturan öğeler arasında iç tutarlık bulunmakta olup, insanların herhangi bir konu veya nesne hakkında bildikleri zihinsel öğeyi, konu veya duruma hangi duygular ile yaklaşacakları (olumlu, olumsuz ya da çekimser) dugusal öğeyi, konu veya duruma yönelik olarak hangi tavırları ortaya koyacakları da davranışsal öğeyi oluşturmaktadır (İnceoğlu, 2010). Insanların tutumlarının davranışa dönüşmesinde davranışsal öğenin büyük bir etkisi bulunmaktadır. $\mathrm{Bu}$ nedenle davranışsal öğe, uyancıya ilişkin olarak yapılan değerlendirmenin davranışa dönüşmesini ifade etmektedir (Karadağ, 2012). Diğer bir ifade ile davranışsal öğe, bireyin tutumun nesnesine ilişskin eğilimini ifade etmektedir (Aras, 2013). İnsanların olay, kişi ya da nesnelere yönelik tutumları sergilenen davranışlara yansıdığı için insanların sahip oldukları tutumların dışarıdan gözlenelebilmesi münkündür (İnceoğlu, 2010).

İnsan davranışlarını şekillendiren tutumlar eğitim sistemi içerisinde de öğrencilerin derslere yönelik yaklaşımlarını, ilgilerini ve akademik başarı düzeylerini etkilemektedir. Beden eğitimi dersi ele alındığı zaman, öğrencilerin beden eğitimi dersine yönelik olumlu tutuma sahip olamalarının ders amaçlarına ulaşmaya yardımcı olmaktadır (Başer, 2009). Bunun yanında öğrencilerin beden eğitimi dersine yönelik olumlu tutuma sahip olmaları beden eğitimi öğretmenlerinin derse yönelik motivasyonlarını arttırmakta, buna parallel olarak öğretmenlerin beden eğitimi derslerini daha verimli işlemelerine katkı sağlamaktadır (Çelik ve Pulur, 2011). Buna karşıllk öğrencilerin beden eğitimi dersine yönelik tutumlarının olumsuz olması öğrencilerin ders verimlerini düşürmekte, derse verdikleri önemi azaltmakta ve öğrencilerin dersin işlenişnde bazı sorunlar çıkarmalarına zemin hazırlamaktadır (Karadă̆, 2012; Güllü ve Güçlü, 2009).

Eğitim sistemi içerisinde öğrencilerin akademik başarısını etkileyen diğer bir unsur güdülenmedir (Çakmak vd., 2008). Kavramsal açıdan ele alındığı zaman güdülenme, insanları harekete geçiren, sergilenecek olan hareketlerin yönünü belirleyen bir olgudur (Yapıc1 ve Yapıc1, 2010). Genel olarak güdülenme içsel ve dısssal güdülenme olarak ikiye ayrilmaktadır. İçsel güdülenme bireyin içinde bulunan mevcut ihtiyaçlarına yönelik tepkileri ifade etmektedir. Öğrencilerin merak, yeterli olma isteği, bilme ihtiyacı ve gelişme arzusu içsel güdülere örnek gösterilebilir. Dışsal güdülenme de ise bireyin dışından gelen etkiler söz konusudur. Öğrencinin yüksek not aldığı için öğretmeni tarafindan övülerek pekiştirilmesi dişsal güdülenmeye örnek gösterilebilir (Selçuk, 2008).

Güdülenme organizmayı belirli tepkilerde bulunmaya, buna parallel olarak yeni birşeyler öğrenmeye zorlamaktadır. Bu nedenle güdülenme öğrenme için gerekli olan şartların başında gelmektedir. Yeterince güdülenmemiş olan bir öğrencinin öğrenmeye hazır hale gelmesi mümkün değildir (Selçuk, 2008). Sınıf ortamında derse güdülenme düzeyi yüksek olan öğrenciler ile güdülenme düzeyi düşük öğrenciler arasındaki farklılıklar çok kolay ayırt edilebilmektedir. Derslerde başarısız olan öğrencilerde genellikle derslere yönelik güdülenme eksikliği bulunmaktadır (Dilekmen ve Ada, 2005). Bu nedenle öğrencilerin öğrenme süreçlerinin başında öğrenmeye yönelik güdülenme düzeylerinin yüksek olması önemli bir durumdur (Erden ve Akman, 2008).

Öğrencilerin beden eğitimi ve spor dersine yönelik tutumlarını etkileyen unsurların iyi bilinmesi öğrencilerin beden eğitimi dersine yönelik tutumlarının geliştirilmesine yönelik önlemlerin alınmasına katkı sağlamaktadır (Zengin ve diğerleri, 2016). Literatürde öğrencilerin beden eğitimi dersine yönelik öğrencileri tutumlarının incelendiği çalışmalarda genellikle öğrencilerin sahip oldukları bazı sosyo demografik özelliklerin (yaş, cinsiyet, spor yapma durumu, eğitim kademesi) beden eğitimi dersine yönelik tutum (Ekici ve diğerleri, 2011; Flintoff ve Scraton, 2001; Zeng ve diğerleri, 2011; Chung ve Philips, 2002; Zengin ve diğerleri, 2016) üzerindeki etkilerinin ele alındığ1 çalışmaların öğrencilerin beden eğitimi dersine yönelik güdülenme düzeylerinin ele alındığ1 çalışmalarda ise beden eğitimi dersine yönelik motivasyon kaynaklarının ele alındı̆̆ı görülmektedir (Hassandra ve diğerleri, 2003). Bunun yanında literatürde öğrencilerin beden eğitimi dersine yönelik tutumları ile derse yönelik güdülenme düzeyleri arasında anlamlı bir ilişki olduğunu ortaya koyan araştırma bulguları bulunmaktadır (Sproule ve diğerleri, 2007; Akandere ve diğerleri, 2010). Bu 
Uluışı, V., Beyleroğlu, M., Suna, N., \& Yalçın, S. (2016). Ortaöğretim öğrencilerinin beden eğitimi dersine ilişkin tutumları ve akademik güdülenme düzeylerinin bazı değişkenlere göre incelenmesi (Burdur il merkezi örneği). Journal of Human Sciences, 13(3), 5092-5106. doi:10.14687/jhs.v13i3.4026

durum öğrencilerin beden eğitimi ders başarılarının arttırılmasında beden eğitimi dersine yönelik tutum ve güdülenme düzeyinin önemli bir etkiye sahip olduğunu göstermektedir. Buna karşllik ülkemizde bu konuda yapılan araştırmalanın sınırlı olduğu görülmüştür. Bu kapsamda yapılan bu araştırmada ortaöğretim öğrencilerinin beden eğitimi dersine ilişkin tutumları ve akademik güdülenme düzeyleri arasındaki ilişkinin, bunun yanında beden eğitimi dersine yönelik tutum ve akademik güdülenme düzeyinin çeşitli değişkenlere göre incelenmesi amaçlanmıştır.

\section{Yöntem}

$\mathrm{Bu}$ araştırma, lise öğrencilerinin beden eğitimi dersine ilişkin tutumlarını ve öğrencilerin akademik güdülenmelerine ilişkin algılarını ve bu ikisi arasındaki ilişkiyi belirlemeye yönelik tarama modelinde bir çalışmadır.

\section{Evren-Örneklem}

Araştırmamızın örneklem gurubunu burdur il merkezinde bulunan Uso Anadolu Lisesi, Mehmet Uzal Sosyal Bilimler Lisesi Emekevler Mesleki ve Teknik Anadolu (Kız Meslek) Lisesi ve Burdur Mesleki ve Teknik Anadolu (Endüstri Meslek) Lisesi'nde öğrenim gören 9., 10., 11., ve 12. Sinıf öğrencileri oluşturmaktadır. Anketimiz 5851 ortaöğretim öğrencisinin eğitim gördüğü burdur il merkezindeki adı belirtilen okullarda tesadüfi örneklem yöntemiyle seçilen 400 öğrenciye uygulanmıştır. Toplanan anket formlarından 15 tanesi hatalı ya da eksik doldurulmuş olmasından dolayı elenerek 385 anket formu değerlendirmeye alınmıştır. Anketle toplanan veriler SPSS.22 paket programı kullanılarak analiz edilmiştir.

\section{Veri Toplama Araçları}

Verilerin toplanmasında anket formu kullanılmıştır. Öğrencilere uygulanan anket formu demografik bilgiler, beden eğitimi dersi tutum ölçeği ve akademik güdülenme ölçeği olmak üzere üç bölümden oluşmaktadır. Anketin demografik bilgiler kısmında yaş, cinsiyet, sınıf, lisanslı spor yapma durumu ile ilgili sorular bulunmaktadir.

Tutum Ölçeği: Tutum ölçeği olarak Güllü M. ve Güçlü M. (2009) tarafindan, ortaöğretim öğrencilerinin beden eğitimi dersine ilişkin tutumlarını incelemek için geliştirilen "Ortaöğretim Öğrencileri İçin Beden Eğitimi Dersi Tutum Ölçeği” kullanılmıştır. Tutum ölçeğinde cevaplar 5 dereceli Likert tipi “(1) Tamamen Katılmiyorum, (2) Katılmiyorum, (3) Kararsızım, (4) Kattliyorum ve (5) Tamamen Katıllyorum" şeklindedir. Ölçeğin 11 maddesi olumsuz madde (3,17, $19,20,24,25,26,29,30,34,35)$ ve 24 maddesi olumlu(1,2,4,5,6,7,8, 9,10,11,12,13,14,15,16, $18,21,22,23,27,28,31,32,33)$ olmak üzere toplam 35 maddeden oluşmaktadır. Ölçeği geliştiren tarafından ölçeğin Cronbach's Alpha güvenirlik katsayısına bakılmıştır ve araştırmacılar tarafindan yüksek bir değer olarak kabul edilen güvenirlik katsayısı 0,94 bulunmuştur.

Akademik Güdülenme Ölçeği: Araştırmada kullanılan akademik güdülenme ölçeği 2004 yllında Bozanoğlu tarafından geliştirilmiştir ve 20 ifadeden oluşmaktadır. Ölçekteki maddeler yanıtlayıcıya kendisine uygun olup olmadığ1 bakımından yine Likert tipi 5'li dereceleme ölçeği ile puanlanmaktadır. (1= Kesinlikle uygun değil, 2= Uygun değil, 3=Kararsızım, 4= Uygun5= Kesinlikle uygun). Ölçekten alınabilecek en yüksek puan 100 ve en düşük puan 20'dir. Elde edilen puanın yüksek olması, akademik güdülenmenin de yüksek olduğunu göstermektedir. Ölçeğin sadece 4. Maddesi tersine puanlanmıştr. Bozanoğlu tarafindan ölçeğin güvenirliği üzerine yapılan çalışmada 101 lise öğrencisinin katıldığ1 test-tekrar test yöntemi kullanılmış ve iki uygulama arasındaki 
Uluışı, V., Beyleroğlu, M., Suna, N., \& Yalçın, S. (2016). Ortaöğretim öğrencilerinin beden eğitimi dersine ilişkin tutumları ve akademik güdülenme düzeylerinin bazı değişkenlere göre incelenmesi (Burdur il merkezi örneği). Journal of Human Sciences, 13(3), 5092-5106. doi:10.14687/jhs.v13i3.4026

korelasyonun 0.87 olduğu bulunmuştur. Hesaplanan Cronbach Alfa iç tutarlılık katsayıları ise farklı zamanlarda aynı guruba uygulandığında 0.77 ile 0.85 , farklı gruplarda ise 0.77 ile 0.86 arasında değiştiği belirtilmiştir.

\section{Verilerin Analizi}

Elde edilen verilerin analizinde SPSS 22.0 programı kullanılmıştır. Ölçek verileri analiz edilmeden önce verilerin güvenilir olup olmadığı incelenmiştir. Yapılan güvenilirlik analizi sonucunda Ortaöğretim Öğrencileri İçin Beden Eğitimi Dersi Tutum Ölçeği’ne ilişkin Cronbach's Alpha iç tutarlık kat sayısı ,913 olarak bulunurken, Akademik Güdüleme Ölçeği'ne ilişkin Cronbach's Alpha iç tutarlık kat sayısı ,902 olarak bulunmuştur. Bu değerler her iki ölçeğinde yüksek düzeyde güvenilir olduğunu göstermektedir. Ölçek verilerinin demografik değişkenlere göre karşılaştırılması yapılmadan önce verilerin normal dağılıma uygun olup olmadığı One Sample Kolmogorov-Smirnov testi ile incelenmiştir. Test sonucunda here iki ölçeğe ilişkin verilerin de normal dağılım göstermediği tespit edilmiştir. $\mathrm{Bu}$ nedenle non-parametrik analiz yöntemleri kullanılmıştır. Katılımcıların cinsiyetlerine göre lisanslı olarak spor yapma durumlarına göre ölçek puanlarını karşılaştırmak için Mann Whitney $U$ analizi kullanıllırken, yaş gruplanı, sınıf düzeyleri ve eğitim gördükleri okul türlerine göre ölçek verilerini karşılaştırmak için Kruskal Wallis $H$ analizi kullanılmıştır. Kruskal Wallis H analizi sonucunda grupların arasında anlamlı farklılık bulunması durumunda post hoc test olarak Mann Whitney U analizi uygulanmıştır. Tutum Ölçeği ve Akademik Güdüleme Ölçeği’nin birbirleriyle arasında ilişkinin incelenmesinde ise Spearman Korelasyon analizi uygulanmıstır. Mann Whitney U, Kruskal Wallis H ve Spearman Korelasyon analizlerinde anlamll1k düzeyi “ $\mathrm{p}<0,05$ ” olarak belirlenmiştir.

\section{BULGULAR}

Tablo 1. Katılımcıların Demografik Bilgilerine İlişkin Frekans ve Yüzdelik Dağılımlar

\begin{tabular}{cccc}
\hline Değişkenler & Alt Değişkenler & f & \% \\
\hline \multirow{2}{*}{ Cinsiyet } & Kadın & 191 & 49,6 \\
& Erkek & 194 & 50,4 \\
\hline Lisanslı spor & Evet & 85 & 22,1 \\
yapma durumu & Hayır & 300 & 77,9 \\
\hline \multirow{3}{*}{ Yaş grupları } & 14 & 70 & 18,2 \\
& 15 & 111 & 28,8 \\
& 16 & 79 & 20,5 \\
& 17 & 102 & 26,5 \\
Sinıf düzeyleri & 18 ve üzeri & 23 & 6,0 \\
& 9. sinıf & 59 & 48,1 \\
& 10, sinıf & 113 & 15,3 \\
& 11, sinıf & 28 & 29,4 \\
& 12, sinıf & 110 & 7,3 \\
\hline \multirow{2}{*}{ Okul türü } & Anadolu Lisesi & 106 & 28,6 \\
& Meslek Lisesi(Endüstri) & 102 & 27,5 \\
& Sosyal Bilimler Lisesi & 67 & 26,5 \\
& Kiz Meslek Lisesi & & 17,4 \\
\hline
\end{tabular}


Uluışı, V., Beyleroğlu, M., Suna, N., \& Yalçın, S. (2016). Ortaöğretim öğrencilerinin beden eğitimi dersine ilişkin tutumları ve akademik güdülenme düzeylerinin bazı değişkenlere göre incelenmesi (Burdur il merkezi örneği). Journal of Human Sciences, 13(3), 5092-5106. doi:10.14687/ihs.v13i3.4026

Yukandaki tabloda araştırmaya katılan öğrencilerin demografik bilgileri yer almaktadır. Tabloda dikkat çeken noktalardan birisi lisanslı spor yapan öğrenci sayısının yüzde 22,1'de kalmış olmasıdır.

Tablo 2. Katılımcıların Beden Eğitimi Dersine İlişkin Tutumlarına Ait Tanımlayıcı İstatistikler

\begin{tabular}{ccccc}
\hline $\mathbf{N}$ & En düşük & En yüksek & $\mathbf{X}$ & Ss \\
\hline 385 & 48 & 174 & 122,50 & 24,430 \\
\hline
\end{tabular}

Tablo 3. Katllımcıların Akademik Güdüleme Düzeylerine Ait Tanımlayıcı İstatistikler

\begin{tabular}{ccccc}
\hline $\mathbf{N}$ & En düşük & En yüksek & $\mathbf{X}$ & Ss \\
\hline 385 & 20 & 100 & 69,70 & 13,495 \\
\hline
\end{tabular}

Tablo 2 ve Tablo 3 incelendiğinde katulımcıların, hem beden eğitimi dersine ilişkin tutumlarının hem de akademik güdüleme düzeylerinin orta düzeyin üzerinde olduğu görülmektedir.

Tablo 4. Katılımcıların Cinsiyetine Göre Beden Eğitimi Dersine İlişkin Tutumlarının Karşılaştırılması

\begin{tabular}{cccccccc}
\hline Cinsiyet & $\mathbf{N}$ & $\mathbf{X}$ & Ss & Sira Ort. & S1ra Top. & U & p \\
\cline { 1 - 6 } Kadın & 191 & 123,33 & 24,276 & 197,89 & 37797,5 & \multirow{2}{*}{17592,5} & \multirow{2}{*}{392} \\
\cline { 1 - 5 } Erkek & 194 & 121,68 & 24,616 & 188,18 & 36507,5 & & \\
\hline
\end{tabular}

Tablo 4'e göre kattlımcıların cinsiyetlerine göre beden eğitimi dersine ilişkin tutumları arasında istatistiksel olarak anlamlı farkllık bulunmamaktadır $(\mathrm{p}>0,05)$.

Tablo 5. Katılımcıların Cinsiyetine Göre Akademik Güdüleme Düzeylerinin Karşılaştırılması

\begin{tabular}{cccccccc}
\hline Cinsiyet & $\mathbf{N}$ & $\mathbf{X}$ & Ss & S1ra Ort. & S1ra Top. & U & p \\
\cline { 1 - 6 } Kadın & 191 & 69,68 & 14,133 & 194,65 & 37178,0 & \multirow{2}{*}{18212,0} & \multirow{2}{*}{773} \\
\cline { 1 - 6 } Erkek & 194 & 69,71 & 12,872 & 191,38 & 37127,0 & & \\
\hline
\end{tabular}

Tablo 5'e göre katılımcıların cinsiyetlerine göre akademik güdüleme düzeyleri arasında istatistiksel olarak anlamlı farklılık bulunmamaktadır ( $p>0,05)$.

Tablo 6. Katılımcıların Yaş Gruplarına Göre Beden Eğitimi Dersine İlişkin Tutumlarının Karşılaştırılması

\begin{tabular}{|c|c|c|c|c|c|c|}
\hline Yaş Grupları & $\mathbf{N}$ & $\mathbf{X}$ & Ss & $\begin{array}{l}\text { Sira } \\
\text { Ort. }\end{array}$ & $\mathbf{X}^{2}$ & $\mathrm{p}$ \\
\hline 14 yaş & 70 & 117,47 & 22,662 & 172,29 & \multirow{5}{*}{4,929} & \multirow{5}{*}{,295 } \\
\hline 15 yaş & 111 & 122,75 & 25,148 & 194,59 & & \\
\hline 16 yaș & 79 & 120,96 & 27,228 & 185,95 & & \\
\hline 17 yaș & 102 & 126,07 & 22,772 & 207,62 & & \\
\hline $18+$ yaş & 23 & 126,00 & 21,772 & 207,74 & & \\
\hline
\end{tabular}

Tablo incelendiğine katılımcıların yaş gruplanına göre beden eğitimi dersine ilişkin tutum düzeyleri arasında istatistiksel olarak anlamlı farklılık olmadığı görülmektedir ( $\mathrm{p}>0,05)$. 
Uluışık, V., Beyleroğlu, M., Suna, N., \& Yalçın, S. (2016). Ortaöğretim öğrencilerinin beden eğitimi dersine ilişkin tutumları ve akademik güdülenme düzeylerinin bazı değişkenlere göre incelenmesi (Burdur il merkezi örneği). Journal of Human Sciences, 13(3), 5092-5106. doi:10.14687/jhs.v13i3.4026

Tablo 7. Katılımcıların Yaş Gruplarına Göre Akademik Güdüleme Düzeylerinin Karşılaştırılması

\begin{tabular}{|c|c|c|c|c|c|c|}
\hline Yaş Gruplanı & $\mathbf{N}$ & $\mathbf{X}$ & Ss & $\begin{array}{l}\text { Sira } \\
\text { Ort. }\end{array}$ & $\mathbf{X}^{2}$ & $\mathrm{p}$ \\
\hline 14 yaş & 70 & 66,63 & 14,802 & 173,18 & \multirow{5}{*}{14,230} & \multirow{5}{*}{,007 } \\
\hline 15 yaş & 111 & 73,34 & 13,515 & 221,92 & & \\
\hline 16 yaş & 79 & 67,68 & 13,590 & 174,52 & & \\
\hline 17 yaş & 102 & 68,60 & 12,189 & 183,07 & & \\
\hline $18+$ yaș & 23 & 73,22 & 10,548 & 221,26 & & \\
\hline
\end{tabular}

Tablo incelendiğinde katılımcıların yaş gruplarına göre akademik güdüleme düzeyleri arasında istatistiksel olarak anlamlı farklılık olduğu görülmektedir $(\mathrm{p}<0,05)$. Bu farklılık, 15 yaş grubundaki katılımcıların akademik güdüleme düzeylerinin 14 yaş, 16 yaş ve 17 yaş grubundaki katılımcıların akademik güdüleme düzeylerinden yüksek olmasından ve $18+$ yaş grubundaki katıllmciların akademik güdüleme düzeylerinin 14 yaş grubundaki katılimcılardan yüksek olmasından kaynaklanmaktadır.

Tablo 8. Katllımcıların Sınıf Düzeylerine Göre Beden Eğitimi Dersine İlişkin Tutumlarının Karşılaştırılması

\begin{tabular}{|c|c|c|c|c|c|c|}
\hline Sınıf Düzeyleri & $\mathbf{N}$ & $\mathbf{X}$ & Ss & $\begin{array}{l}\text { Sira } \\
\text { Ort. }\end{array}$ & $\mathbf{X}^{2}$ & $\mathrm{p}$ \\
\hline 9. sinif & 185 & 118,68 & 24,051 & 176,74 & \multirow{4}{*}{14,027} & \multirow{4}{*}{,003 } \\
\hline 10. sinif & 59 & 130,86 & 27,248 & 231,66 & & \\
\hline 11. sinif & 113 & 122,14 & 22,110 & 190,57 & & \\
\hline 12. sinif & 28 & 131,54 & 24,188 & 228,80 & & \\
\hline
\end{tabular}

Katulımcıların beden eğitimi dersine ilişkin tutumları sınıf düzeylerine göre istatiksel olarak anlamlı farkllılı göstermektedir $(\mathrm{p}<0,05)$. Bu farklılık, 9.sınıfta öğrenim gören katulımciların tutum düzeyinin 10.sınıf ve 12.sınıfta öğrenim gören katılımcılardan düşük olmasından ve 11.sınıfta öğrenim gören katılımcıların tutum düzeyinin 12.sınıfta öğrenim gören katılımcılardan düşük olmasindan kaynaklanmaktadır.

Tablo 9. Katulımcıların Sınıf Düzeylerine Göre Akademik Güdüleme Düzeylerinin Karşılaştırılması

\begin{tabular}{|c|c|c|c|c|c|c|}
\hline Sınıf Düzeyleri & $\mathbf{N}$ & $\mathbf{X}$ & Ss & $\begin{array}{l}\text { Sira } \\
\text { Ort. }\end{array}$ & $\mathrm{X}^{2}$ & $\mathrm{p}$ \\
\hline 9. sinif & 185 & 69,75 & 14,374 & 194,83 & \multirow{4}{*}{4,018} & \multirow{4}{*}{,260 } \\
\hline 10, sinif & 59 & 71,98 & 14,151 & 213,24 & & \\
\hline 11, sinif & 113 & 68,27 & 11,882 & 178,34 & & \\
\hline 12, sinıf & 28 & 70,29 & 12,076 & 197,45 & & \\
\hline
\end{tabular}

Kattlımcıların akademik güdüleme düzeyleri sınıf düzeylerine göre istatistiksel olarak anlamlı farkl1l1k göstermemektedir ( $\mathrm{p}>0,05)$. 
Uluışık, V., Beyleroğlu, M., Suna, N., \& Yalçın, S. (2016). Ortaöğretim öğrencilerinin beden eğitimi dersine ilişkin tutumları ve akademik güdülenme düzeylerinin bazı değişkenlere göre incelenmesi (Burdur il merkezi örneği). Journal of Human Sciences, 13(3), 5092-5106. doi:10.14687/jhs.v13i3.4026

Tablo 10. Katılımcıların Eğitim Gördükleri Okul Türüne Göre Beden Eğitimi Dersine İlişkin Tutumlarının Karşılaştırılması

\begin{tabular}{|c|c|c|c|c|c|c|}
\hline Okul Türleri & $\mathbf{N}$ & $\mathbf{X}$ & Ss & $\begin{array}{l}\text { S1ra } \\
\text { Ort. }\end{array}$ & $\mathbf{X}^{2}$ & $\mathrm{p}$ \\
\hline Anadolu Lisesi ve Dengi Okullar & 110 & 125,63 & 24,608 & 206,70 & \multirow{4}{*}{20,253} & \multirow{4}{*}{, 000} \\
\hline Meslek Lisesi(Endüstri) & 106 & 114,31 & 24,378 & 154,17 & & \\
\hline Sosyal Bilimler Lisesi & 102 & 128,14 & 24,422 & 219,24 & & \\
\hline Kız Meslek Lisesi & 67 & 121,72 & 20,986 & 191,98 & & \\
\hline
\end{tabular}

Tablo incelendiğinde katılımcıların beden eğitimi dersine ilişkin tutumlarının okul türüne göre istatistiksel olarak anlamlı düzeyde farklılaştı̆̆ görülmektedir $(\mathrm{p}<0,05)$. Bu farklıllk, Meslek Lisesi’nde (Endüstri) eğitim gören katılımcıların tutum düzeylerinin diğer okullarda eğitim gören katılımcılardan düşük olmasından kaynaklanmaktadır.

Tablo 11. Katılımcıların Eğitim Gördükleri Okul Türüne Göre Akademik Güdüleme Düzeylerinin Karşılaştırılması

\begin{tabular}{|c|c|c|c|c|c|c|}
\hline Okul Türleri & $\mathbf{N}$ & $\mathbf{X}$ & Ss & $\begin{array}{l}\text { S1ra } \\
\text { Ort. }\end{array}$ & $\mathrm{X}^{2}$ & $\mathbf{p}$ \\
\hline Anadolu Lisesi ve Dengi Okullar & 110 & 70,54 & 13,397 & 202,00 & \multirow{4}{*}{2,830} & \multirow{4}{*}{,419 } \\
\hline Meslek Lisesi(Endüstri) & 106 & 69,25 & 12,201 & 185,60 & & \\
\hline Sosyal Bilimler Lisesi & 102 & 68,23 & 13,679 & 182,97 & & \\
\hline Kız Meslek Lisesi & 67 & 71,25 & 15,254 & 205,21 & & \\
\hline
\end{tabular}

Kattlımcıların akademik güdüleme düzeyleri eğitim gördükleri okul türüne göre istatistiksel olarak anlamlı farklılık göstermemektedir $(\mathrm{p}>0,05)$.

Tablo 12. Katılımcıların Lisanslı Spor Yapma Durumlarına Göre Beden Eğitimi Dersine İlişkin Tutumlarının Karşılaştırılması

\begin{tabular}{cccccccc}
\hline $\begin{array}{c}\text { Lisanslı } \\
\begin{array}{c}\text { Spor yapma } \\
\text { durumu }\end{array}\end{array}$ & $\mathbf{N}$ & $\mathbf{X}$ & Ss & Sira Ort. & Sira Top. & $\mathbf{U}$ & $\mathbf{p}$ \\
\cline { 1 - 6 } Evet & 85 & 128,15 & 27,037 & 218,04 & 18533,0 & 10622,0 & \multirow{2}{*}{019} \\
\hline Hayır & 300 & 120,89 & 23,440 & 185,91 & 55772,0 & \\
\hline
\end{tabular}

Tablo 12 incelendiğinde lisanslı olarak spor yapan ve yapmayan katılımcıların beden eğitimi dersine ilişkin tutum düzeyleri arasında farklılık olduğu görülmektedir $(\mathrm{p}<0,05)$. Lisanslı olarak spor yapan katılımcıların beden eğitimi dersine ilişkin tutum düzeyleri daha yüksektir.

Tablo 13. Katılımcıların Lisanslı Spor Yapma Durumlanına Göre Akademik Güdüleme Düzeylerinin Karşılaştırılması

\begin{tabular}{cccccccc}
\hline $\begin{array}{c}\text { Lisansli } \\
\text { Spor } \\
\text { yapma } \\
\text { durumu }\end{array}$ & $\mathbf{N}$ & $\mathbf{X}$ & Ss & Sira Ort. & Sira Top. & $\mathbf{U}$ & $\mathbf{p}$ \\
\hline Evet & 85 & 69,26 & 14,361 & 189,52 & 16109,0 & 12454,0 &, 743 \\
\hline Hayır & 300 & 69,82 & 13,261 & 193,99 & 58196,0 & \\
\hline
\end{tabular}

Katılımcıların lisanslı olarak spor yapma durumlarına göre akademik güdüleme düzeyleri arasında istatistiksel olarak anlamlı farkllikk bulunmamaktadır $(\mathrm{p}>0,05)$. 
Uluıșık, V., Beyleroğlu, M., Suna, N., \& Yalçın, S. (2016). Ortaöğretim öğrencilerinin beden eğitimi dersine ilișkin tutumları ve akademik güdülenme düzeylerinin bazı değişkenlere göre incelenmesi (Burdur il merkezi örneği). Journal of Human Sciences, 13(3), 5092-5106. doi:10.14687/jhs.v13i3.4026

Tablo 14. Katılımcıların Beden Eğitimi Dersine İlişkin Tutum Düzeyleri ile Akademik Güdüleme Düzeyleri Arasındaki İlișkinin İncelenmesi

\begin{tabular}{ccc}
\hline & Korelasyon & Akademik Güdüleme \\
\hline \multirow{3}{*}{ Tutum } & $\mathrm{r}$ &, 233 \\
\cline { 2 - 3 } & $\mathrm{p}$ &, 000 \\
\cline { 2 - 3 } & $\mathrm{n}$ & 385 \\
\hline
\end{tabular}

Tablo 14 incelendiğinde katılımcıların beden eğitimi dersine ilişkin tutum düzeyleri ile akademik güdüleme düzeyleri arasında doğrusal (zayıf) ve anlamlı bir ilişki olduğu tespit edilmiştir $(\mathrm{p}<0,05)$.

\section{Tartışma}

Araştıtrmaya katılan öğrencilerin beden eğitimi dersine yönelik tutumlarının ve akademik güdülenme güdülenme düzeylerinin orta düzeyin üzerinde olduğu tespit edilmiştir. Literatürde yer alan benzer araştırmalarda da eğitim sistemi içerisinde beden eğitimi ve spor dersine yönelik öğrenci tutumlarının genel olarak olumlu olduğunu göstermektedir (Güllü, 2007). Bu kapsamda araştırmada elde edilen bulguların literatür ile paralellik gösterdiği söylenebilir.

Araştırmaya katılan öğrencilerin beden eğitimi dersine yönelik tutumlarının cinsiyet değişkenine göre istatistiksel açıdan anlamlı farklılık göstermediği tespit edilmiştir. Bu sonucun ortaya çıkmasının temelinde müfredat içerisinde beden eğitimi ve spor derslerinin hem kadın hem de erkek öğrenciler tarafından sevilen derslerin başında gelmesinin yattığı düşünülebilir. Literatürde yer alan araşturma bulgularının da araştırmada elde edilen bu sonucu desteklediği görülmektedir (Taşmektepligil vd., 2006; Gürbüz ve Özkan, 2012; Zengin vd., 2016; Alpaslan, 2008). Uluışı (2015) tarafindan yapılan araştırmada ortaöğretim öğrencşlerinin beden eğitimi dersine yönelik tutumlarını etkileyen demografik değşkenlerin incelenmesi amaçlanmıştır. Araştırmada cinsiyet değişkenine göre ele alındığ1 zaman ortaöğretim öğrencilerinin beden eğitimi dersine yönelik tutumlarının benzerlik gösterdiği tespit edilmiştir. Keskin (2015) tarafından yapılan benzer bir araştırmada cinsiyetin beden eğitimi dersine yönelik tutum üzerinde önemli bir belirleyici olmadığ1 tespit edilmiş, kadın ve erkek öğrencilerin benzer sosyo-demografik çevrelerde yetişmelerinin bu sonucun ortaya çımasında etkili olabileceği vurgulanmıştır. Zengin ve diğerleri (2016) tarafindan ortaokul ve ortaöğretim öğrencileri üzerinde yapılan araştırmada da cinsiyet unsurunun beden eğitimi ve spor dersine yönelik tutum üzerine önemli bir belirleyici olmadığı bulunmuş, bunun temelinde kadın ve erkek öğrencilerin benzer sosyal yapı özelliklerine sahip olmalarının yattığı ifade edilmiştir.

Araştırmaya katılan öğrencilerin akademik güdülenme düzeylerinin cinsiyet değişkenine göre istatistiksel açıdan anlamlı farklılık göstermediği tespit edilmiştir. Buna karşıllk literatürde yer alan araştırma bulguları cinsiyet değişkeninin akademik başarı motivasyonu ve güdülenme üzerinde anlamlı bir etkiye sahip olduğunu ortaya koymaktadır. Akandere ve diğerleri (20101) tarafindan yapılan araştırmada ortaöğretim öğrencilerinin akademik başarı motivasyonu düzeylerinin cinsiyet değişkenine göre incelenmesi amaçlanmıs, araştırmanın sonunda kadın dışsal motivasyon düzeyinin öğrencilerin, motivasyonsuzluk düzeyinin ise erkek öğrenciler lehine daha yüksek olduğu tespit edilmiştir. Aynı araştırmada kadın ve erkek öğrencilerin akademik başarı motivasyonu alt boyutlarından olan içsel motivasyon düzeylerinin cinsiyet değişkenine göre istatistiksel açıdan anlamlı farklılık göstermediği sonucuna ulaşılmıştır. Bu kapsamda araştırma elde edilen bulguların literatür ile paralellik gösterdiği söylenebilir.

Araştırmaya katılan öğrencilerin beden eğitimi dersine yönelik tutumlarının yaş gruplarına göre istatistiksel açıdan anlamlı farklılık göstermediği tespit edilmiştir.Araştırma bulgularını destekleyen benzer bir çalışmada yaş unsurunun ortaöğretim öğrencilerinin beden eğitimi dersine yönelik tutumlarını etkilemediği bulunmuştur (Güllü, 2007). Akandere vd., (2010)tarafindan ortaöğretim öğrencileri üzerinde yapılan araştırmada ise yaş değişkeninin beden eğitimi dersine yönelik tutumları 
Uluıșık, V., Beyleroğlu, M., Suna, N., \& Yalçın, S. (2016). Ortaöğretim öğrencilerinin beden eğitimi dersine ilișkin tutumları ve akademik güdülenme düzeylerinin bazı değişkenlere göre incelenmesi (Burdur il merkezi örneği). Journal of Human Sciences, 13(3), 5092-5106. doi:10.14687/jhs.v13i3.4026

etkilediği tespit edilmiştir. Elde edilen bulgulara göre 14-16 yaş grubunda bulunan öğrencilerin beden eğitimi dersine yönelik tutumlarının 17-19 yaş grubundaki katulımcılardan istatistiksel açıdan anlamlı düzeyde daha yüksek olduğu sonucuna ulaşılmıştır. Literatürde yer alan araştırma bulguları ile yapılan bu araştırmada elde edilen sonuçların çelişkili olduğu görülmektedir. Bunun temelinde araştırmalara katılan öğrencilerin öğrenim gördükleri liselerin ders içerikleri ve amaçlarının birbirinden farklı olması, öğrencilerin yaş grupları itibaryle beden eğitimi ve spordan beklentilerinin farklı olması gibi unsurların yattı̆̆ düşünülebilir.

Araştırmaya katılan öğrencilerin akademik güdülenme düzeylerinin yaş gruplarına göre istatistiksel açıdan anlamlı farklılık gösterdiği tespit edilmiştir. Elde edilen bulgulara göre, 15 yaş grubundaki katılımcıların akademik güdüleme düzeylerinin 14 yaş, 16 yaş ve 17 yaş grubundaki katılımcıların akademik güdüleme düzeylerinden, bunun yanında $18+$ yaş grubundaki katılımcıların akademik güdüleme düzeylerinin 14 yaş grubundaki katılımcılardan daha yüksek olduğu sonucuna ulaşılmıştır. Akandere ve diğerleri (2010) tarafindan ortaöğretim öğrencileri üzerinde yapılan benzer bir araştırmada da öğrencilerin akademik başarı motivasyonlarının yaş grubu değişkenine göre istatistiksel açıdan anlamlı farklılık gösterdiği tespit edilmiştir. Söz konusu araştırmada 17-19 yaş ile 20 ve üzerinde yaş grubunda bulunan ortaöğretim öğrencileri ile kıyaslandığ zaman 14-16 yaş grubunda bulunan öğrencilerin içsel ve dışsal motivasyon düzeylerinin istatistiksel açıdan daha yüksek olduğu sonucuna ulaşılmıştır. Araştırmada elde edilen bulgular ile literatürde yer alan araştırma bulguları göz önünde bulundurulduğu zaman lisa öğrencilerinde yaş unsurunun akademik güdülenmenin önemli bir yordayıcısı olduğu söylenebilir. Bunun temelinde lise öğrencilerinin yaş gruplarına göre derslere yönelik tutumlarının, akademik başarı hedeflerinin ve sınav kaygısı yaşama düzeylerinin farkll1ık göstermesinin yattı̆̆ düşünülebilir.

Araştırmaya katılan öğrencilerin beden eğitimi dersine yönelik tutumlarının öğrenim görülen sınıf değişkenine göre istatistiksel açıdan anlaml farklılık gösterdiği tespit edilmiştir. Elde edilen bulgulara göre, 9.sınıfta öğrenim gören katılımcıların tutum düzeyinin 10.sınıf ve 12.sınıfta öğrenim gören katılımcılardan düşük olduğu, bunun yanında 11.sinıfta öğrenim gören katılımcıların tutum düzeyinin 12.sınıfta öğrenim gören katulımcılardan düşük bulunduğu belirlenmiştir. Araştırmada elde edilen bu bulgular ortaöğretim öğrencilerinin sınıf düzeyleri arttıkça beden eğitimi dersine yönelik tutumlarının da arttı̆̆ sonucunu ortaya koymaktadır. Uluışı (2015) tarafından ortaöğretim öğrencileri üzerinde yapılan araştırmada ise öğrencilerin sınıf düzeyleri arttıkça beden eğitimi dersine yönelik tutumlarının azaldığı sonucuna ulaşılmıştır. Güllü (2007) tarafindan ortaöğretim öğrencileri üzerinde yapılan diğer bir araştırmada öğrenim görülen sınıf değişkeni açısından 10. ve 11. sınıf öğrencilerinin beden eğitimi dersine yönelik tutumlarının istatistiksel açıdan anlamlı farklılık gösterdiği tespit edilmiş, elde edilen bulgulara göre 11. sınıf öğrencileri ile kıyaslandığı zaman 10. sınıf öğrencilerinin beden eğitimi dersine yönelik tutumlarının daha olumlu olduğu belirlenmiştir. Alpaslan (2008) tarafindan yapılan araştırmada diğer sınıflarda öğrenim gören öğrenciler ile kıyaslandığ1 zaman beden eğitimi dersine yönelik olarak en yüksek tutum puanına 10. sınıf öğrencilerinin sahip olduğu bulunmuştur. Görüldügü gibi ortaöğretim öğrencilerinin sinıf değişkenine göre beden eğitimi dersine yönelik tutumlarına ilisskin araştırma bulgularının çelişkili sonuçlar ortaya koymaktadır. Bunun temelinde araştırmalara katılan öğrencilerin farklı lise türlerinde eğitim almalarının ve araştımaların gerçekleştirildiği okulların sportif imkan bakımından farklı Özelliklere sahip olmalarının yattı̆̆ düşünülebilir.

Araştırmaya katılan öğrencilerin akademik güdülenme düzeylerinin öğrenim görülen sınıf değişkenine göre istatistiksel açıdan anlamlı farklılık göstermediği tespit edilmiştir. Çakmak vd., (2008) tarafindan yapılan araştırmada ortaokul ve lise öğrencilerinin akademik güdülenme düzeylerinin bazı değişkenlere göre incelenmesi amaçlanmışır. Araştırmada öğrenim görülen sınıf değişkenine göre ele alındığı zaman alt sınıflarda bulunan öğrencilerin akademik güdülenme düzeylerinin üst sınıf öğrencilerine kiyasla daha yüksek olduğu tespit edilmiştir. Bu kapsamda araştırmada elde edilen bulguların literatür ile paralellik göstermediği görülmektedir. 
Uluışı, V., Beyleroğlu, M., Suna, N., \& Yalçın, S. (2016). Ortaöğretim öğrencilerinin beden eğitimi dersine ilişkin tutumları ve akademik güdülenme düzeylerinin bazı değişkenlere göre incelenmesi (Burdur il merkezi örneği). Journal of Human Sciences, 13(3), 5092-5106. doi:10.14687/jhs.v13i3.4026

Araştırmaya katılan öğrencilerin beden eğitimi dersine yönelik tutumlarının öğrenim gördükleri lise türüne göre istatistiksel açıdan anlamlı farklılık gösterdiği tespit edilmiştir. Elde edilen bulgulara göre, diğer liselerde öğrenim gören öğrenciler ile kiyaslandığı zaman Meslek Lisesi’nde (Endüstri) öğrenim gören katıllımcıların tutum düzeylerinin daha düşük olduğu sonucuna ulaşılmıştır. Güllü (2007) tarafindan yapılan benzer bir çalışmada ortaöğretim öğrencilerinin beden eğitimi dersine yönelik tutumlarının öğrenim görülen okul türüne göre incelenmesi amaçlanmış, araşturmanın sonunda meslek lisesi öğrencileri ile kıyaslandığı zaman genel lise öğrencilerinin beden eğitimi dersine yönelik tutumlarının anlamlı düzeyde daha yüksek olduğu tespit edilmisstir. Araştırmada öğrencilerin beden eğitimi dersine yönelik tutumlarının okul türüne göre farklılık göstermesinin temelinde genel liseler ile meslek liseleri arasında amaç farklılıkları bulunmasının, bu durumun da öğrencilerin derslere yönelik tutumlarını etkilemesinin yattı̆̆ı vurgulanmıştır.

Araştırmaya katılan öğrencilerin akademik güdülenme düzeylerinin öğrenim gördükleri lise türüne göre istatistiksel açıdan anlamlı farklılık göstermediği tespit edilmiştir. Bu sonucun ortaya çıkmasının temelinde farklı liselerde öğrenim görmelerine ragmen araştırmaya katılan öğrencileri derslere motive eden unsurların benzerlik göstermesinin yattı̆̆ düşünülebilir.

Araştırmaya katılan öğrencilerin beden eğitimi dersine yönelik tutumlarının lisanslı olarak spor yapma durumlarına göre istatistiksel açıdan anlamlı farklılık gösterdiği tespit edilmiştir. Elde edilen bulgulara göre, lisanslım olarak spor yapan öğrencilerin beden eğitimi dersine yönelik tutumlarının lisanslı olarak spor yapma alıskanllğ bulunmayan öğrencilerden daha yüksek olduğu sonucuna ulaşılmıştır. Literatürde yer alan araştırma bulguları değerlendirildiği zaman, genel olarak spora katılımın beden eğitimi dersine yönelik tutumları pozitif yönde etkilediği (Akandere vd., 2010; Chung ve Philips, 2002), lisanslı spor yapan öğrencilerin beden eğitimi dersine yönelik tutumlarının sedanter öğrencilerden daha yüksek olduğu (Kangalgil vd., 2006; Güllü, 2007; Alpaslan, 2008), bu kapsamda araştırmada elde edilen bulguların literatürle paralellik gösterdiği görülmektedir. Güllü (2007) tarafindan yapılan araştırmada ders dışı spor etkinliklerine katılan öğrencilerin beden eğitimi dersine yönelik tutumlarının olumlu olmasının temelinde spora etkinliklşerine katılan öğrencilerin beden eğitimi derslerine yönelik ilgi ve sevgilerinin de yüksek olmasının yattığı ifade edilmiştir.

Araştırmaya katılan öğrencilerin akademik güdülenme düzeylerinin lisanslı olarak spor yapma durumlarına göre istatistiksel açıdan anlamlı farklılık göstermediği tespit edilmiştir. Literatürde yer alan araştırmalar incelendiği zaman spora katılımın akademik başarı motivasyonu ve derslere yönelik güdülenme üzerinde olumlu bir etkiye sahip olduğu görülmektedir. Akandere ve diğerleri (2010) tarafindan ortaöğretim öğrencileri üzerinde yapılan araştırmada düzenli olarak spor yapma alışkanlığ1 bulunan öğrencilerin akademik başarı motivasyonu alt boyutlarından olan içsel motivasyon düzeylerinin nadiren spor yapan ortaöğrencileri ile hiç spor yapmayan öğrencilerden anlamlı düzeyde daha yüksek olduğu tespit edilmiştir. Bu kapsamda araştırmada elde edilen bulguların literatür ile paralellik göstermediği görülmektedir. Bunun temelinde araştırmaya katılan lisanslı sporcular ile sedanter lise öğrencileri arasında ciddi bir oransal dağılımın farkı olmasının yattı̆̆1 düşünülebilir. Nitekim araştırmaya katılan öğrencilerin sadece \%22,1'inin lisanslı olarak spor yaptıkları bulunmuştur.

Araştırmaya katılan öğrencilerin beden eğitimi dersine ilişkin tutum düzeyleri ile akademik güdüleme düzeyleri arasında doğrusal (zayıf) ve anlamlı bir ilişki olduğu tespit edilmiştir. Akandere ve diğerleri (2010) tarafindan yapılan benzer bir araştırmada ortaöğretim öğrencilerinin beden eğitimi dersine yönelik tutumları ile akademik başarı motivasyonlanı arasındaki ilişkinin incelenmesi amaçlanmıştır. 9, 10 ve 11 'inci sınıf öğrencileri üzerinde gerçekleştirilen araştırmada akademik başarı motivasyonu alt boyutları olan içsel ve dışsal motivasyon düzeyi ile beden eğitimi dersine yönelik tutum puanları arasında istatistiksel açıdan anlamlı bir ilişki bulunduğu tespit edilmiştir. Sproule vd., (2007) tarafindan yapılan benzer bir araştırmada öğrencilerin akademik güdülenme düzeylerinin beden eğitimi dersine yönelik yaklaşımlarını etkilediği sonucuna ulaşılmışırı. Literatürde yer alan araştırma bulguları değerlendirildiği zaman, araştırmada elde edilen bulguların literatür ile paralellik 
Uluıșık, V., Beyleroğlu, M., Suna, N., \& Yalçın, S. (2016). Ortaöğretim öğrencilerinin beden eğitimi dersine ilișkin tutumları ve akademik güdülenme düzeylerinin bazı değişkenlere göre incelenmesi (Burdur il merkezi örneği). Journal of Human Sciences, 13(3), 5092-5106. doi:10.14687/jhs.v13i3.4026

gösterdiği, bu kapsamda akademik güdülenme düzeyinin beden eğitimi dersine yönelik tutumları etkilediği söylenebilir.

\section{Sonuç ve Öneriler}

Yapılan bu araştırmanın sonunda, ortaöğretim öğrencilerinin beden eğitimi dersine yönelik tutumlarının öğrenim görülen sınıf düzeyi, okul türü ve lisanslı olarak spor yapma değişkenlerine göre istatistiksel açıdan anlamlı farklılık gösterdiği, buna karşılık yaş ve cinsiyet değişklenlerine göre öğrencilerin beden eğitimi dersine yönelik tutumlarının farklılık göstermediği sonucuna ulaşılmıştır. Akademik güdülenme ile ilgili bulgular değerlendirildiği zaman, öğrencilerin akademik güdülenme düzeylerinin sadece yaş grubu değişkenine göre anlamlı farkllık gösterdiği, diğer değişkenlerin ise (cinsiyet, sınıf düzeyi, okul türü, lisanslı olarak spor yapma durumu) akademik güdülenme üzerinde anlamlı bir etkiye sahip olmadığ bulunmuştur. Bunun yanında öğrencilerin beden eğitimi dersine yönelik tutum düzeyleri ile akademik güdülenme düzeyleri arasında istatistiksel açıdan anlamlı bir ilişki olduğu sonucuna ulaşılmıştır. Araştırmada elde edilen bulguların genel olarak literatür ile paralellik gösterdiği görülmüştür. Araştırmada elde edilen bulgular ışığında araştırma konusu ile ilgili olarak aşağıdaki önerilerde bulunulabilir;

1. Daha büyük örneklem grupları ile benzer araştırmalar yapılabilir. Bunun yanında farklı sosyodemografik ve sosyo-ekonomik özelliklere sahip olan lise öğrencileri üzerinde benzer araştırmalar uygulanabilir.

2. Ortaöğretim öğrencilerinin beden eğitimi dersine yönelik tutumlarını ve akademik güdülenme düzeylerini olumsuz yönde etkileyen unsurların belirlenmesine yönelik araştırmalar yapılabilir.

3. Ortaöğretim öğrencilerinin beden eğitimi ve spor dersine yönelik tutumları ile akademik güdülenme düzeyleri arasında anlamlı bir ilişki bulunduğu göz önünde bulundurularak, ortaööğretim öğrencilerinin akademik güdülenme düzeylerini arttırmak adına ders içi ve ders dış1 spor etkinliklerine katılımın arttırılmasına yönelik düzenlemeler yapılabilir.

\section{Kaynaklar}

Açak, M. (20016). Beden Eğitimi Öğretmeninin El Kitabı. İstanbul: Morpa Kültür Yayınları.

Akandere, M., Özyalvaç, N.T., Duman, S. (2010). Ortaöğretim Öğrencilerinin Beden Eğitimi Dersine Yönelik Tutumlanı İle Akademik Başarı Motivasyonlarının İncelenmesi (Konya Anadolu Lisesi Örneği). Selçuk Üniversitesi Sosyal Bilimler Enstitüsü Dergisi, 24: 1-10.

Alpaslan, S. (2008). Ortaöğretim Öğrencilerinin Beden Eğitimi Öğretmenlerinin Sergilediği Öğretim Davranışlarına İlişkin Algıları ve Öğrencilerin Bu Derse Karşı Geliştirdikleri Tutumları. Yülesek Lisans Tezi. Bolu: Abant İzet Baysal Üniversitesi Sosyal Bilimler Enstitüsü.

Aras, Ö. (2013). İlköğretim Kurumları İkinci Kademede Öğrenim Gören Öğrenci Ve Görev Yapan Beden Eğitimi Öğretmenlerinin Beden Eğitimi Dersine Yönelik Görüş Ve Tutumlarının İncelenmesi (Kars İli Örneği). Yükesek Lisans Teæi. Ankara: Gazi Üniversitesi.

Başer, S. A. (2009). Öğretmen Niteliklerinin Beden Eğitimi Dersi Alan Öğrencilerin Bu Derse Karşı Olan Tutumlarına Etkisi. Yükesek Lisans Teq̨i. . Bolu: Abant İzzet Baysal Üniversitesi.

Chung, M. H., Phillips, D. A. (2002). The Relationship between Attitude toward Physical Education and Leisure-Time Exercise in High School Students. Physical Educator, 59(3): 126-38.

Çakmak, E.K., Akgün, Ö.E., Karadeniz, Ş., Büyüköztürk, Ş., Demirel, F. (2008). İlköğretim İkinci Kademe Ve Lise Öğrencilerinin Ders ve Sınıf Düzeylerine Göre Öğrenme Stratejileri ve Güdülenme Düzeylerinin Belirlenmesi. Uluslararası Insan Bilimleri Dergisi, 5(1): 1-27. 
Uluıșık, V., Beyleroğlu, M., Suna, N., \& Yalçın, S. (2016). Ortaöğretim öğrencilerinin beden eğitimi dersine ilișkin tutumları ve akademik güdülenme düzeylerinin bazı değişkenlere göre incelenmesi (Burdur il merkezi örneği). Journal of Human Sciences, 13(3), 5092-5106. doi:10.14687/jhs.v13i3.4026

Çelik, Z., Pulur, A. (2011). Ortaöğretim Öğrencilerinin Beden Eğitimi ve Spora İlişkin Tutumları. Yüzüncü Yal Üniversitesi Eg̈itim Fakültesi Dergisi, Özel Say1:115-121.

Çoban, B., Ünveren, A. (2007). Beden Eğitimi ve Oyun Ögretimi. Oğuzhan Zirek (Editör). Ankara: Nobel Yayın Dağıtım.

Dilekmen, M., Ada, Ş. (2005). Öğrenmede Güdülenme. Kąım Karabekir Eğitim Fakültesi Dergisi, 11: 113-123.

Ekici, S., Bayrakdar, A., Hacıcaferoğlu, B. (2011). Lise Öğrencilerinin Beden Eğitimi Dersi Tutumlarının Değerlendirilmesi. Uluslararasi İnsan Bilimleri Dergisi, 8(1): 829-839.

Erden, M., Akman, Y. (2008). Eğitim Psikolojisi. 17. Baskı. Ankara: Arkadaş Yayınevi.

Flintoff, A., Scraton, S. (2001). Stepping Into Active Leisure? Young Women's Perceptions of Active Lifestyles And Their Experiences of School Physical Education. Sport, Education and Society, 6(1): 5-21.

Güllü, M. (2007). Ortaöğretim Öğrencilerinin Beden Eğitimi Dersine Yönelik Tutumlarının Araştırılması. Doktora Tezi. Ankara: Gazi Üniversitesi.

Güllü, M., Güçlü, M. (2009). Ortaöğretim Öğrencileri İçin Beden Eğitimi Dersi Tutum Ölçeği Geliştirilmesi. Niğde Üniversitesi Beden Eğitimi ve Spor Bilimleri Dergisi, 3(2): 138-151.

Gürbüz, A., Özkan, H. (2012). İlköğretim İkinci Kademe Öğrencilerinin Beden Eğitimi Ve Spor Dersine İlişkin Tutumlarının Belirlenmesi (Muğla İl Örneği). Pamukkale Journal of Sport Sciences, 3(2): 78-89.

Hassandra, M., Goudas, M., Chroni, S. (2003). Examining Factors Associated With Intrinsic Motivation in Physical Education: a Qualitative Approach. Psychology of Sport and Exercise, 4: 211-223.

Hekim, M. (2015). Cocuk Gelişimi ve Eğitiminde Beden Eğitimi Derslerinin Yeri ve Önemi. VII. Uluslararası Eğitim Araştırmaları Kongresi Kongre Bildiri Özet Kitabı. 21-23 Mayıs 2015, Muğla Sıtkı Koçman Üniversitesi, Muğla.

Hekim, M. (2016). Çocuklarda Beden Eğitimi, Spor ve Oyun Etkinliklerine Katılımın Kemik Gelişimi Üzerine Etkilerinin Değerlendirilmesi. Gümüşhane Üniversitesi Sağhlk Bilimleri Dergisi, 5(2): 66-71.

Hekim, M., Tokgöz, M., Reyhan, S., Yıldırım, Y. (2012). Spor Yapan ve Yapmayan 12-14 Yaş Grubu Kız Çocuklarının Bazı Motorik Özelliklerinin Karşılaştırılması. Uluslararası Hakemli Spor Sağllk ve Tip Bilimleri Dergisi, 3(2): 31-38.

İnceoğlu, M. (2010). Tutum Algı İletişim. Beşinci baskı. İstanbul: Beykent Üniversitesi Yayınevi.

Kangalgil, M., Hünük, D., Demirhan, G. (2006). İlköğretim, Lise ve Üniversite Öğrencilerinin Beden Eğitimi ve Spora İlişkin Tutumlarının Karşılaştırılması. Hacettepe Journal of Sport Sciences, 17(2): 48-57.

Karadağ, E. (2010). Eğitim Bilimleri Doktora Tezlerinde Kullanılan Araştırma Modelleri: Nitelik Düzeyleri ve Analitik Hata Tipleri. Kuram ve Uygulamada Eğitim Yönetimi, 16(1): 49-71.

Keskin, B., Güvendi, B., Altınc1, E. E. (2014, May1s). Sporun Bedensel Engellilerin Sosyallesmeleri Üzerine Etkisi. I. Uluslararası Spor Bilimleri turizm ve Rekreasyon Öğrenci Kongresi, Akdeniz Üniversitesi, Antalya.

Keskin, Ö. (2015). Ortaokul Öğrencilerinin Beden Eğitimi Dersine Yönelik Tutumlarının Bazı Değişkenlere Göre İncelenmesi (Sakarya İli Örneği). Sakarya: Yükesek Lisans Tę̧i. Sakarya Üniversitesi.

Salar, B., Hekim, M., Tokgöz, M. (2012). 15-18 Yaş Grubu Takım ve Ferdi Spor Yapan Bireylerin Duygusal Durumlarının Karşılaştırılması. Mehmet Akif Ersoy Üniversitesi Sosyal Bilimler Enstitïï̈ Dergisi, 4(6): 123-135.

Selçuk, Z. (2008). Eğ̈itim Psikolojisi. 15. Baskı. Ankara: Nobel Yayın Dağıtım.

Sproule, J., John Wang, C. K., Morgan, K., McNeill, M., McMorris, T. (2007). Effects of motivational climate in Singaporean physical education lessons on intrinsic motivation and physical activity intention. Personality and Individual Differences, 43: 1037-1049. 
Uluışı, V., Beyleroğlu, M., Suna, N., \& Yalçın, S. (2016). Ortaöğretim öğrencilerinin beden eğitimi dersine ilişkin tutumları ve akademik güdülenme düzeylerinin bazı değişkenlere göre incelenmesi (Burdur il merkezi örneği). Journal of Human Sciences, 13(3), 5092-5106. doi:10.14687/jhs.v13i3.4026

Şahin, S., Işıtan, S. (2010, Ekim). Özel Sporlarn Özel Oyuncusu Olmak: Vaka Sunumu. II. Ulusal Engelli Bireyler İçin Fiziksel Aktivite Çalıştayı, Çanakkale Onsekiz Mart Üniversitesi, Çanakkale.

Taşmektepligil, Y., Yılmaz, Ç., İmamoğlu, O., Kılcıgil, E. (2006). İlköğretim Okullarında Beden Eğitimi Ders Hedeflerinin Gerçekleşme Düzeyi. SPORMETRE Beden Eğitimi ve Spor Bilimleri Dergisi, 4(4): 139-147.

Uluışı, V. (2015). Ortaöğretim Öğrencilerinin Beden Eğitimi Dersine Yönelik Tutumlarının Sınıf ve Cinsiyet Değişkenlerine Göre İncelenmesi. Uluslararası Multidisipliner Akademik Arastırmalar Dergisi, 2(3): 45-53.

Yapıc1, S.., Yapıc1, M. (2010). Eğitim Psikolojisi. 2. Baskı. Ankara: Anı Yayınc1lık.

Zeng H. Z., Hipscher M., Leung R. W. (2011). Attitudes of High School Students toward Physical Education and Their Sport Activity Preferences. Journal of Social Sciences, 7 (4): 529-537.

Zengin, M., Hekim, M., Hekim, H. (2016). Ortaokul ve Lise Öğrencilerinin Beden Eğitimi Dersine Yönelik Tutumlarının Cinsiyet ve Öğrenim Kademesi Değişkenine Göre İncelenmesi. Uluslararasi Insan Bilimleri Dergisi, 13(2): 3242-3251.

\section{Extended English Abstract}

In this study, it was purposed that the investigation of relationship between secondary school students' attitudes of physical education lesson and academic motivation. Franzor (2003) interpreted attitude in terms of "assessment of individual to an object as positive or negative". Demirhan and Altay (2001) pointed out that attitudes may be at various degrees from most positive to most negative. As to physical education is described as active life style which do with the aim of providing enjoyable participation to student development with physical activities at school physical education programs, their knowledge, attitudes, motor and behavioral skills and contains physical continuity (Pate, Corbin and Pangrazi, 1998). As to academic motivation, Bozanoğlu (2004) describes as production of energy for academic activities. Student' the relevance of interest to school, academic success, sensibility and care in tasks and homework which are given at school, shortly positive-negative attitudes related to school and learning gives information about academic motivation. This study is a research in model of scanning which purpose to identify secondary school students' attitudes of physical education and perceptions related to their academic motivation and relationship between these. Totally 385 secondary school students as 191 females and 194 males, who take education Uso Anatolian Secondary school, Mehmet Uzal Social Sciences Secondary school, Emekevler Vocational and Technique Anatolian (Girl's Vocational School) Secondary school and Burdur Vocational and Technique Anatolian (Industrial School) Secondary school, participated to research. Survey form was used in collection of data. Survey form consists of three parts as demographic information, physical education attitude scale and academic motivation scale. Questions related age, gender, class, doing licensed sport status appear in demographic information of survey. Attitude Scale of Physical Education Lesson for Secondary School Students, developed by Güllü M. and Güçlü M. (2009) to investigate students' attitudes of physical education, was used as attitude scale. Answers in attitude scale is in terms of five-likert scale as "1) Completely disagree, (2) Disagree, (3) Undecided, (4) Agree and (5) Completely Agree". Cronbach's Alpha reliability coefficient was looked by developers and reliability coefficient was found as 0,94 which is accepted by as high value researcher. Academic Motivation Scale was developed by Bozanoğlu at 2004 year and it consists of 20 questions. Answers is in terms of five-likert scale on account of suit or not to responders' themselves. 1) Completely unsuited, (2) Unsuited, (3) Undecided, (4) Suited (5) Completely Suited. Maximum score, which can be taken from scale, is 100 and minimum score 
Uluıșık, V., Beyleroğlu, M., Suna, N., \& Yalçın, S. (2016). Ortaöğretim öğrencilerinin beden eğitimi dersine ilișkin tutumları ve akademik güdülenme düzeylerinin bazı değişkenlere göre incelenmesi (Burdur il merkezi örneği). Journal of Human Sciences, 13(3), 5092-5106. doi:10.14687/jhs.v13i3.4026

is 20. In study on scale reliability by Bozanoğlu, test-retest method, that 101 secondary school student participated, used and correlation between two applications was found as 0,87 . When Cronbach's Alpha reliability coefficients were applied same group at different times, switched 0.77 and $0.85,0.77$ and switched 0.86 in different groups. SPSS 22.0 program was used in analysis of data obtained. Before analysis of data obtained, it was investigated again whether data are reliable or not. In result of applied reliability analysis, while Cronbach's Alpha reliability coefficients for Attitude Scale of Physical Education Lesson for Secondary School Students was found as ",913", Cronbach's Alpha reliability coefficients for Academic Motivation Scale was found as ",902". These values indicate that both scales are reliable at high level. It was investigated whether scale data are conformed to normal or not by using One Sample Kolmogorov-Smirnov test before scale data were compared as demographic variables. In result of test, it was established that data are not conformed to normal distribution. So, non-parametric analysis methods were used. While Mann Whitney $\mathrm{U}$ analysis was used to compare scale scores as gender and doing licensed sport status, Kruskal Wallis $\mathrm{H}$ analysis was used to compare scale scores as age groups and class levels and school types which are taken education. In case there are significant difference among groups, Mann Whitney U analysis was applied as post hoc test. Spearman Correlation analysis was used in investigation of relationship between Attitude Scale and Academic Motivation Scale. Significant level was determined as " $\mathrm{p}<0,05$ " in Mann Whitney U, Kruskal Wallis H and Spearman Correlation analyses. As findings obtained from this study, no significant difference was found when we looked students' attitude related to physical education lesson, but, 15 age group participants' academic motivation levels were higher than 14 age, 16 age and 17 age group participants when we looked academic motivation levels. When participants' academic motivation levels as school types were looked, it was seen that academic motivation levels did not show significant level $(p>0,05)$. But, it was seen that participants' attitudes of physical education lesson were differentiated as school types $(p<0,05)$. When we looked participants' attitudes of physical education lesson as class levels, significant differences were seen $(p<0,05)$. When we looked participants' academic motivation levels as class levels, significant differences were not established ( $p>0,05)$. There was no significant difference between academic motivation levels as doing licensed sport status $(p>0,05)$. But, it was seen that there was significant difference between doing licensed sport participants' and nonlicensed sport participants' attitude level related physical education $(p<0,05)$. In result of research, it was established that there was linear (weak) and significant relationship between secondary school students' attitude levels related to physical education and academic motivation levels $(p<0,05)$. So, as long as participants' attitude related to physical education is increased, academic motivation levels is increased. Another words, we can say as long as academic motivation level is increased, attitude related to physical education is increased. 